\section{Threats to Contemporary Economic Order}

\author{
Janusz Klisiński \\ University of Bielsko-Biala, Poland \\ D https://orcid.org/0000-0002-5233-8041
}

Political Preferences

2020, vol. 26: 69-76

journals.us.edu.pl/index.php/PP

Submitted: 05/06/2020

Accepted: 21/06/2020

\section{Pol}

Pre

Abstract:

The biggest threats to contemporary economic order were chronologically the bipolarity of the world after 1945, in which one of the poles despised money and the other based its prosperity on money. An attempt to create a unipolar world already dominated by the US dollar, practically was hardly acceptable. The US showed its strength when Japan in 1995 became a pretender to be No. 1 in the global economy. Also in 2008, American banks triggered a global financial crisis by creating bubbles of toxic real estate loans. The 2008 financial crisis also started a crisis of liberal democracy. China was much more powerful than Japan as the next pretender to become No. 1 in the global economy. About it can be seen as the beginning of a global conflict between the United States and China. In addition, the coronavirus pandemic has stopped globalization and is causing a global crisis.

Keywords: biopolar world, unipolar world, crisis of liberal democracy, global conflict, coronavirus pandemic, globalization

\title{
Introduction
}

The purpose of the article is to identify threats to the contemporary economic order in historical terms. It is assumed that the US-China rivalry and the accompanying economic hard to predict COVID-19 are a serious threat to the economic order, outweighing all threats from the last seventy-five years.

\section{The collapse of Biopolar World}

After World War II, until 1989, there was a balance of two: the West, headed by the US and the East (socialist) headed by the USSR. From the beginning, the socialist order was based on the contempt for money. However, money has created the modern economy. We call this process of creating the world economy - globalization. Money was created by the West from nothing, both in central banks as an order for the mint and in commercial banks as an entry in the accounts.

The USSR and other socialist countries could only queue for loans, because it was the only way to acquire Western know-how. But when lenders turned on the know-how tap from 
West to East and started enforcing the flow of goods from East to West (to pay off the loans), the borrowers fell into a classic debt trap. It was the West that dictated the conditions. In December 1991, the USSR was liquidated. In the post-Soviet area and in the former European countries of people's democracy, the socialist system was broken and market transformations of the economies started. Their peaceful colonization with the use of money took place (Szafarz 2013: 70).

\section{An attempt to create a unipolar world by the US}

It is understandable why countries such as Russia (but also others) do not want to subordinate to another state. In general, the question arises - why does America reinforce such a unipolar world? It is obvious that neither Russia nor China would want a unipolar world under the leadership of one authority on the other side of the Atlantic. Therefore, if the United States do not abandon such goals, Russia and China will be forced to unite. The association of countries in BRICS in 2006 to create a new currency system not based on the dominance of the US dollar is the first manifestation of the unification of countries in the opposition to the US. BRICS - is the term for a group of developing countries - Brazil, Russia, India, China and South Africa since 2011 (Mowle \& Sacko 2007: 70). In 2019, the GDP of all BRIC states amounted to approximately 46.22 billion international dollars (GDP of the BRIC 2020)

The goals of these countries are:

- Creating new monetary system.

- Increasing the role of developing countries in global monetary institutions.

- Reforming the United Nations.

\section{Economic miracle and fall of Japan}

In 1965-1980, Japan had a 12-fold increase in GDP from \$ 91 billion. up to 1.0 trillion dollars. There was talk of economic miracle. In 1995, Japan's GDP was already USD 5.3 trillion. and the US 7.6 trillion dollars, even though Japan had 2.5 times less population than the US. In 1995 GDP per capita in Japan was \$ 42,522 and in the US only \$28,782. In 1995, the 10 largest banks in the world belonged to the Japanese. Japan has become the largest creditor and the US has become the largest debtor. In the same year Japan became a contender for position number one in the global economy. The largest banks of the world in 1988 were Dai-ichi Kangyo Bank, Sumitomo Bank, Fuji Bank, Mitsubishi Bank, Sanwa Bank, Industrial Bank of Japan, 
Norinchukin Bank, Mitsubishi Trust\&Banking Co., Sumitomo Trust \&Banking Co. and Tokai Bank.

The USA and the richest countries in the world have required Japan Agreement Plaza - an agreement on the appreciation (increase in purchasing power) of the Japanese yen against the US dollar from a ratio of 250:1 to 149:1. The competitiveness of products exported from Japan has decreased. The US also required Japan to reduce interest rates to 2.5\%. Morgan Stanley and Salomon Brothers (investment banking and services for business clients) appeared on the Japanese stock exchange and began selling derivative products, i.e. secondary market securities, to Japanese entrepreneurs. Instead of curing, the Japanese government's treatments based on Keynesianism did harm. Japan has entered a phase of economic stagnation that continues to this day (Bowles \& Woods 2000: 85). In 2015, the US GDP amounted to USD 18 trillion, and Japan dropped by $14 \%$ compared to 1995 and amounted to USD 4.1 trillion. In 2015, GDP per capita in the USA was USD 56 116, and in Japan only 32471 USD (GDP 2015).

\section{The financial crisis of 2008 and the crisis of liberal democracy}

The first symptoms of the crisis were recorded in January 2007. September 15, 2008 - on Black Monday, American financiers at the New York Federal Reserve headquarters decided to bankrupt the American Lehman Brothers bank. The government decided not to support the 158-year-old American investment bank, one of the oldest and largest in the world. News of the bank's bankruptcy caused a collapse on global stock exchanges. It was American banks that were responsible for creating a bubble of toxic real estate loans. Over 10 million American families lost their homes, and millions more had to pay back loans far beyond the value of their property. In Europe, the crisis has hit not only over-indebted countries like Greece or Italy, but also Ireland and Spain.

The consequences were political turmoil in Southern Europe, an authoritarian turn in Hungary, Russia, Turkey, the strengthening of the PRC, Brexit and Trump's victory in the USA. It was only after German-Chinese consultations in 2012 that Chancellor Merkel decided to leave Greece in the Euro zone. In Hungary, for example, many loans for real estate or cars were sold in Swiss francs or Japanese yen, and monthly installments in forints suddenly increased by $40 \%$. In the fight against world financiers (Dwyer \& Tkac 2009), Wiktor Orban built his campaign and a later career. In Italy, right-wing populist parties, the Northern League and the Five Stars Movement, etc. have come to the fore, in Poland power was gained by the united right, headed by the PiS party (Law and Justice). 
The financial crisis of 2008 caused a crisis of liberal democracy. The essence of the current crisis is that it is not known how and with what result the future world will cope with the new situation. There is a crisis of liberal democracy, a return to national egoisms and the temptation of authoritarian governments, also in Poland. For the world, it is dangerous for the US to return to protectionism, for the European Union Brexit, Polexit and other exits possible in the near future, and finally its disintegration into nation states. This crisis of liberal democracy may take even more severe forms after the defeat of the coronacrisis. Western countries thought that there was no other way than liberal democracy. The West has deprived itself of tools to keep markets under control. Governments have stated that they cannot interfere in economic processes. And China's influence tools have retained. They introduced a combination of market rules and state planning. They did not invent it themselves, Deng Xiaoping ordered to imitate Singapore. Authoritarianism also gives China an advantage over the West. In times of instability and confusion - and in this reality we live today - autocracies have an important advantage: they can react quickly. The example of China showed that the free market gets along well with technocratic authoritarianism (Castells 2019: 112).

\section{The beginning of the global conflict between the US vs China}

The customs war is not about eliminating the trade deficit equal to Poland's annual GDP. It is about exchanging the US consulative attitude for an active one. The US must be active for their corporations to enter the PRC market with investments. Chinese are afraid of this scenario. They are preparing to be not only the strongest economy in the world and set standards for others, but also to increase their advantage. Since the main world currency is the dollar, China has accumulated the world's highest reserves of this currency of 4 trillion. dollars. The second country is Japan, which has currency reserves of 1.1. trillion dollars.

Since 2010, China is the second largest (after the US) and the fastest growing national economy in the world, achieving an average growth rate of $10 \%$ per year over the last 30 years. It is also the largest exporter in the world and the second largest importer. Today China is the most populous country in the world with a population exceeding 1.3 billion, which is $19.1 \%$ of the world population. In terms of area, it is 3rd in the world, and in terms of the size of the economy, second only to the US (in terms of nominal GDP), and 1st in terms of real GDP (Coker 2015).

East China's provinces and urban centers play a special role in the economic development of the PRC. Although this area covers only $9.5 \%$ of the total area of the country, in recent years more than $90 \%$ of China's trade with the world has been realized here, and almost $75 \%$ of the 
value of foreign direct investment located in China has flowed here. The highest income (gross product) is generated in Guangdong Province (Guangzhou), and it is a scale comparable to Poland's GDP. The indicator characterizing the diversity of individual areas of the PRC is the amount of per capita income. Under this classification, Shanghai is leading, ahead of Beijing, Tianjin, Zhejiang Province, Jiangsu and Guangdong. Income per inhabitant of Shanghai is ten times higher than this indicator in Guizhou Province, which ranks last on the list.

China ranks first in the world in terms of trade value. Most machines and equipment are exported. Behind them are textiles and clothing, footwear, toys, sports equipment and fuel. China exports to countries such as the USA (21.1\%), Hong Kong (17.4\%), Japan (13.6\%), South Korea (4.6\%), Germany (4\%). However, machinery, electronic equipment, fuel, plastic, iron, steel and chemicals are imported. The partners of Chinese imports are Japan (18\%), Taiwan (11.9\%), South Korea (10.4\%), USA (8.2\%), and Germany (5.9\%). The Canton Trade Fair plays an important role in the development of foreign trade.

The total number of Chinese soldiers is 2,250,000. The compulsory service in land forces lasts 3 years, and in the navy and aviation 4. The reserve forces number about 12 million soldiers. The Chinese army also oversees the space program. According to the Global Firepower (2014) ranking, Chinese armed forces constitute the third (after the US and Russia) military force in the world with an annual defense budget of USD 126 billion (USD).

China's strength is shown by statistics, facts, trivia:

- $\quad$ The PRC has 48 car brands.

- They are a world leader in the production of electric cars.

- The PRC has 31 mobile telephone producers.

- They are a world leader in the production of supercomputers.

- The PRC has the largest radio telescope in the world with a diameter of $500 \mathrm{~m}$.

- They have the longest high-speed rail network with the highest operating speed above 350 $\mathrm{km} / \mathrm{h}$.

- The longest metro network is in Shanghai. It's $588 \mathrm{~km}$ and 364 metro stations.

- $\quad$ The PRC has 142 thousand km of highways.

- The longest bridge in the world connects Hong Kong with Macao.

- A magnetic rail train connecting the airport with the center of Shanghai is speeding at 437 $\mathrm{km} / \mathrm{h}$.

- $\quad$ The PRC is the country with the largest currency reserves.

- $\quad$ The country has its headquarters 5 largest public companies in the world. 
- The railway in Tibet is the highest railway in the world (5000 $\mathrm{m}$ above sea level).

In the years 2010-2015, foreign direct investment in the amount of USD 250 billion flowed into the Chinese market every year. i.e. as much as to Poland throughout the entire period (Walkowski 2017: 350).

\section{Development prospects for PRC}

The economic invasion of China in Africa and the European Union began. In 2020, the PRC's turnover with Africa will exceed USD 440mld. The Chinese are building schools, factories, skyscrapers, railways and highways in Africa. They provide real assistance to Africa in the form of financing. The transfer of knowledge and technology is delayed. At the same time, they flood the African continent with cheap products, destroying local competition. In Adis Ababa they built the headquarters of the African Union, and in Djiboutia a military base, which is consistent with the assumed goal of achieving number one position in the world by 2049 in all areas. In 2010, Chinese from Geely Automobil bought a Ford company from Göteborg for 1.8 billion USD. In France, the YTO Group took over the Mc Cormick tractor factory in Saint Dizier, which gave them access to modern technology. The Chinese took over the port of Piraeus in Greece for 35 years for EUR 35 million. 2/3 of the port is occupied by COSCO, the Chinese giant on the container transport market.

Xi Jinping's team set two goals for the century. The first is to be achieved in 2021 - the centenary of the Chinese Communist Party - and consists in building a "society of moderate prosperity." Translating this into our western categories, it's about powerful middle class strengthening. Xi Jinping wants the driving force of the Chinese economy to be no longer cheap exports to the. West, but, as he writes, "a thriving internal market": If he succeeds, the products that were exported will be bought by Chinese citizens. Xi Jinping's second goal is to be achieved by 2049 - the centenary of the proclamation of the People's Republic of China - "the great renaissance of the Chinese people". It is primarily about the peaceful unification of China with Taiwan. Taiwan has a GDP comparable to Poland, so if they merged, then the world's number one economy would be created.

The Chinese have also developed the geopolitical project of the New Silk Road. What is the idea of the New Silk Road? This is to be a convenient connection between China and Europe. By sea and land. This sea route ends in the Greek port of Piraeus, and the land route in Łódź in Poland, from which nine branches are to go in different directions. China is afraid that the new 
balance of power in the world will be bipolar: US-China. And they try to do everything to prevent this from happening (Pechlaner et al. 2020).

In 2060, China is foreseen to have an economy twice as strong as the American one. The US will be pushed to third place in the world by India. Already in 2050, we will observe a double advantage of BRICS economies over the G-7 (i.e. a group of seven countries that are one of the most important in the world in economic terms: France, Japan, Germany, the United States, Great Britain, Italy (G6, from 1975) and Canada (G7, from 1976).

It is not known how many poles will arise. In the puzzle, China, the US, India, maybe Russia are important, and the question is whether the European Union will be the fifth major contender to manage the world. Forecasts for 2035 say that the first economy in the world will be China, the second USA, and the third India. In 2050, the order is to change again: the first China, the second India, and the United States only the third. Russia will not be economically strong, because it is too dependent on China, has become a supplier of raw materials for the Chinese economy. In the clash of giants, which has just begun, great India is unknown (Staack 2013:125).

\section{Impact of coronavirus-induced political decisions on the world economy}

The epidemic shock and government decisions to stop working in many industries have already hit the business. The activity of enterprises in the eurozone collapsed on a scale exceeding even what we saw during the apogee of the global financial crisis of 2008-2009. In the world serious economic dislocations can be expected. There is not much known about the results of the coronacrisis yet, although from many comments a more pessimistic picture emerges than from the assessment of 2008-2009. The crisis 2008-2009 began with risky loans granted to consumers for the purchase of real estate, despite the lack of creditworthiness. The crisis of 2020 is the result of the decision of the authorities of many countries to slow down the economy, and actually freeze a large part of socio-economic life, resulting in a lack of income in millions of companies. We have a highly likely bankruptcy for both small and consumer and large companies. We do not know whether the "coronacrisis" will cut off China from the markets in which it has prevailed until now or will make China more dependent on Beijing (Henzel 2020).

And what effects will the global "coronacrisis" cause in Poland? The National Bank of Poland has started printing paper money for purchased bonds on the secondary market. It is possible to reprint cash to the amount of PLN 90 billion, i.e. by 30\%. In addition, the zloty is weakening, as investors are escaping to the dollar and other stronger currencies of the euro, the British pound, the Swiss franc, the yen and even the yuan. This will result in inflation. The NBP 
reduced interest rates by $0.5 \%$ and the required reserve by $3 \%$. At the same time, the NBP increased the interest rate on the required reserve from 0.5 to $1.0 \%$. This will allow commercial banks to offer very attractive loans. Borrowings for investment and consumption purposes will help the economy as well as successively introduced anti-crisis shields 1.2.3.4. etc. In 2020 and the following year, the Polish economy will probably decline. There will be no funds for repolonizing enterprises and banks. The importance of foreign capital in the Polish economy will increase.

\section{Conclusion}

The spark of conflict between the US and China, and nowadays coronavirus crisis is the greatest threat to global economic order. Governments have allocated hundreds of billions of dollars to save the global economy. World leaders faced a terrible choice: to destroy the world economy or lose millions of lives. Coronavirus has accelerated the beginning of the end of the globalization era. It may cause other countries, e.g. Italy, to leave the European Union, as a result of which the community will fall apart. The amount of loss associated with a pandemic will depend primarily on its duration. The prolonged uncertainty caused by it increases the likelihood of the slowdown recorded since 2018 in the global economy, including in the EU, as well as a recession.

\section{References:}

Bowles, P., \& Woods, L. (2000). Japan after the economic miracle. Boston: Kluwer Academic Publishers.

Castells, M. (2019). Rupture: The Crisis of Liberal Democracy. Cambridge: Polity Press.

Coker, Ch. (2015) The Improbable War: China, The United States and Continuing Logic of Great Power Conflict. London : Hurst \& Company.

Dwyer, G. \& Tkac, P. (2009). The financial Crisis of 2008 in Fixed Income Markets. Atlanta: Federal Reserve Bank of Atlanta.

GDP of the BRIC (2020). http://statista.com/statistics/254281/gdp-of-the-bric-coutries/ (01/05/2020).

GDP (2020). Gross Domestic Product. https://countryeconomy.com/gdp (01/02/2020).

Henzel, P. (2020) Pandemia koronowirusa może zmienić oblicze globalizacji. HolisticNews. https://holistic.news/pandemia-koronawirusa-moze-zmienic-oblicze-globalizacji/ (01/05/2020).

Mowle, T., \& Sacko, D. (2007). The Unipolar World: an Unbalanced Future. New York: Palgrave Macmillan.

Pechlaner, H., Erschbamer, G., Thees H., \& Gruber M. (2020). China and the New Silk Road. Basel: Springer.

Staack, M. (2013). Multilateralizm and Multipolarity. Structures of the Emerging World Order. Opladen: Barbara Budrich Publishers.

Szafarz, S. (2013). Narodziny świata wielobiegunowego. Przegląd Socjalistyczny, (1)2, 59-77.

Walkowski, M. (2017). Chiński model rozwoju społeczno-gospodarczego i jego potencjalne adaptacje w Europie. Przegląd Strategiczny, 10, 335-65. 